\title{
八ヶ岳西岳南西斜面に分布するミズナラーチョウセンゴヨウー カラマツ混交林の構造と植生変遷史上の意義
}

\author{
沖津 進 (千葉大学園芸学部)
}

\begin{abstract}
八ヶ岳西岳の南西斜面標高 $1,900 \mathrm{~m}$ 付近にはミズナラ, チョウセンゴヨウ，カラマツの 3 種が混交する, 日本列島では特異な樹種構成の森林が分布している. ここでは, その林分構造を紹介し, 日本列島の森林植 生变遷史を理解する上でこの混交林が重要な位置にあることを指摘する. 胸高断面積比ではミズナラが最も 優占し，チョウセンゴヨウは小径木が多い．カラマツは大径木が主体だが，小径木もある程度存在する。 こ の混交林では優占 3 樹種がほぼ順調に更新している。 このタイプの森林は日本列島ではほかには分布しない. 一方, 北東アジア大陸部ではこれと類似の森林が分布する. 最終水期の寒冷, 乾燥気候条件下では中部日本 にもこの混交林と類似する森林が分布していたと考えられる．その後の温暖，湿润化に伴い，現在の位置に 限定分布するに至ったと推察される。 八ヶ岳西岳の南西斜面は現在でも比較的寒冷, 乾燥気候下にあり, 大 陸型森林のレフュジーアとなり得る地域である。

キーワード : 大陸的気候, レフュジーア, チョウセンゴヨウ, 最終水期, 植生史
\end{abstract}

\section{I はじめに}

日本列島の植生は最終水期以来さまざまな変遷を 経て現在の分布に至っている（安田・三好 1998）. そのため, 現在の植生分布は最終水期のそれとはか なり異なっている（安田・三好 1998）。一方, 現在 でも, 最終水期の遺存植生, あるいはそれに類する ものが日本列島各地に分布している可能性は高い. そうした植生について, その分布立地や, 組成, 構 造, 更新の特徵などを明らかにすることは, 日本列 島における最終水期以降の植生变遷を検討する上で 重要である.

日本列島における最終水期以来の植生変遷が検討 されるなかで, 単独の樹種レベルでは, 後水期に分 布を拡大し, 現在の植生帯を特徴づけている植物や, その逆に, 後水期に分布を縮小したものが浮かび上 がってきた. 前者の例としてオオシラビソAbies mariesii Mast. (梶 1982; 杉田 1990; Sugita 1992)やブナ Fagus crenata Blume (守田 1984, 1985, 1987; 守田・相沢 1986) が, 後者の例として チョウセンゴョウPinus koraiensis Sieb. et Zucc. (百原ほか 1997; 辻 1983, 1987) が挙げられ る. しかし, 植生レベルで, 最終水期以降の遺存植
生とみなされるものについて報告，検討した例はほ とんどない. Yamanaka et al. (1973) は, 山形 県中部月山 $(1,979 \mathrm{~m})$ の東山腹溶岩台地上に分布 するオオシラビソ微少林分の成立過程を花粉分析結 果から検討し, それが最終水期以後の降雪の増加と あいまって衰退していったものの, 遺存植生である と結論している。こうした調査を今後精力的に積み 重ねて行く必要があろう。

八ヶ岳西岳南西斜面には, 狭い範囲ではあるが, ミズナラ Quercus mongolica Fischer ex Ledeb. ーチョウセンゴョウ Pinus koraiensis Sieb. et Zucc.ーカラマッ Larix leptolepis Gord.の 3 樹 種が混交する森林が分布している.こうした樹種構 成は特異で, 日本列島ではほかに類例がない。しか し, 北東アジア大陸部にはこれと類似した森林が広 く分布する. 西岳の気候条件と照らし合わせると, この混交林は, 最終水期以来の遺存植生の可能性が 高い. 本報告ではこの混交林の構造を報告し，それ が持つ最終水期以降の植生変遷史上の意義を考察す る.

なお, ミズナラについては, 日本列島ではQuercus mongolica ssp. crispula (Blume) Menits., Querucs mongolica var. crispula (Blume) 

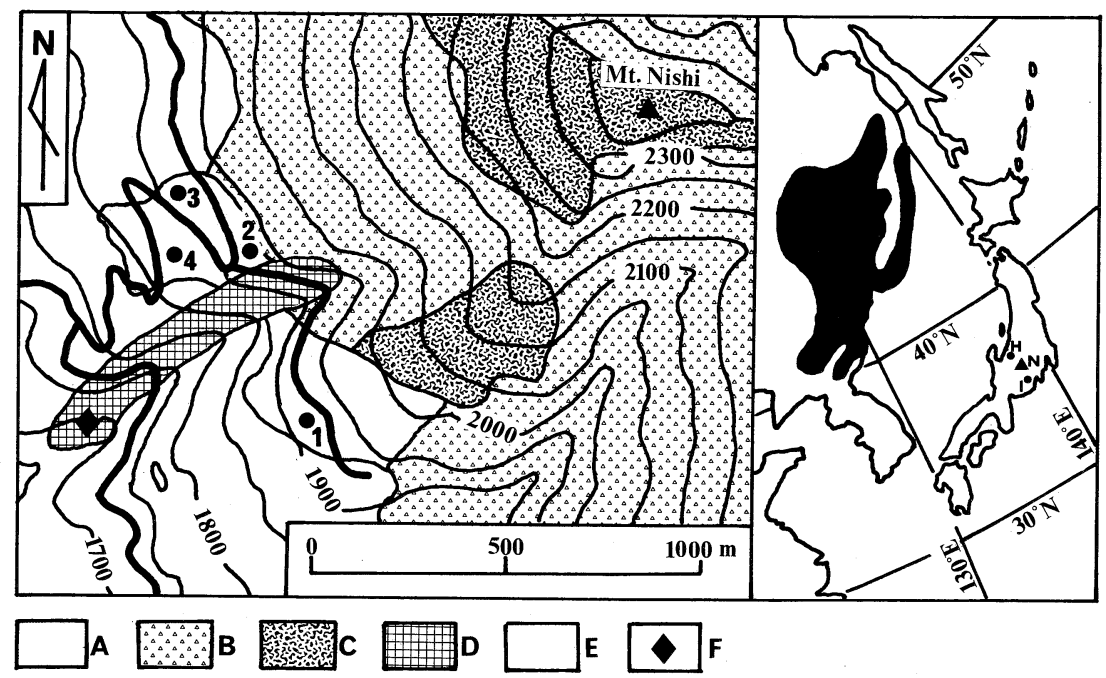

図 1 八ヶ岳南部西岳（標高 $2,398 \mathrm{~m}$ ） 南西斜面の植生図（左図）および北東アジアに おけるチョウセンゴヨウー落葉広葉樹混交林の分布域（黒塗り部分）之西岳 $(\mathrm{N})$, 白馬 $(\mathrm{H})$, 井川 (I) の位置 (右図)

$\mathrm{A}$ : ミズナラーチョウセンゴヨウーカラマツ混交林Ｂ：シラベーオオシラビソーダケカンバ林 $\mathrm{C}$ : シラベーオオシラビソ林 $\quad \mathrm{D}$ : カラマツ天然林 $\mathrm{E}$ : 人工造林地とミズナラ二次林 $\mathrm{F}$ : ヤツガタ ケトウヒ分布地

チョウセンゴョウー落葉広葉樹混交林の分布域は Critchfield and Little (1966), Hou (1983), Yim (1977), Lavrenko and Sochava（1954）を編集して作成. 図中の黒丸（4 力所）は調查区の 位置と番号を示す，等高線間隔は $50 \mathrm{~m}$, 図中の太線は林道を示す。

Fig. 1 Vegetation map around the southwest slope of Mt. Nishi $(2,398 \mathrm{~m}$ in elevation), southern Yatsugatake, central Japan (left figure), and distribution of Pinus koraiensis-deciduous broadleaved mixed forest in northeastern Asia (black area) and the locations of Mt. Nishi (N), Hakuba (H), and Ikawa (I) (right figure)

A: Quercus mongolica-Pinus koraiensis-Larix leptolepis mixed forest $\quad$ B: Abies spp. (A. veitchii, A. mariesii)-Betula ermanii mixed forest C: Abies spp. (A. veitchii, A. mariesii) forest D: Larix leptolepis natural forest E: Artificial forests and Quercus mongolica secondary forest F: A stand of Picea Koyamai

The distribution of Pinus koraiensis-deciduous broadleaved mixed forest is compiled from Critchfield and Little (1966), Hou (1983), Yim (1977), and Lavrenko and Sochava (1954). Four dots with arabic number in the figure show the location of sample plots and their number. Contour intervals are $50 \mathrm{~m}$. Thick line in the figure shows. the forest road.

Ohashiなどとして, 北東アジア大陸部に分布する モンゴリナラ Quercus mongolica Fischer ex Ledeb.の亜種, あるいは变種として取り扱われる ことが多いが，ここでは，日本のミズナラも広義の モンゴリナラに含まれるものとみなして議論を進め る. それは，この混交林と北東アジア大陸部に分布 する森林との関連を考察するためである．和名につ いては, 日本列島のものは慣例にしたがってミズナ

$$
\text { ラとした. }
$$

\section{II 西岳周辺の自然環境}

\section{1. 地形・地質}

西岳（標高 $2,398 \mathrm{~m}$; 北緯 $35^{\circ} 55^{\prime} 12$ ”, 東経 $138^{\circ}$ 22’25”）は, 本州中部, 山梨, 長野県境を南北に約 $21 \mathrm{~km}$ にわたって連なる八ヶ岳の最南部にある高 峰である. 最南端の編笠山 $(2,524 \mathrm{~m})$ から赤岳 
表 1 アメダスデータ (1979 1990 年) による, 白馬 (日本海側), 原村 (西岳西麓), 井川（太平洋側）における月別平均気温と降水量

Table 1 Mean monthly air temperature and precipitation at three AMeDAS stations (Hakuba, Sea of Japan side; Haramura, western foot of Mt. Nishi; Ikawa, Pacific side) from 1979 to 1990

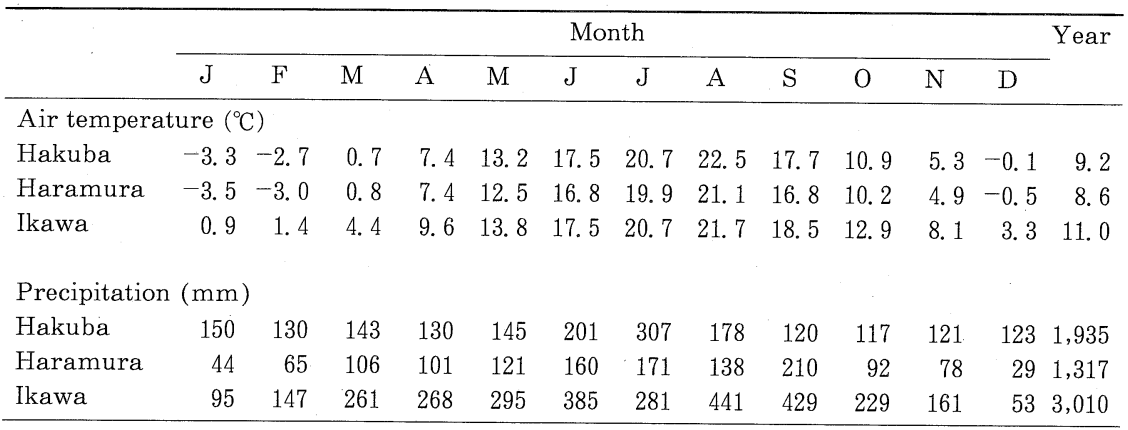

各地点の位置と標高は次の通りである. 白馬, 北緯 $36^{\circ} 41^{\prime} 42^{\prime \prime}$, 東経 $137^{\circ} 51^{\prime} 54^{\prime \prime}, 703 \mathrm{~m}$; 原村, 北緯 $35^{\circ} 58^{\prime} 6^{\prime \prime}$, 東経 $138^{\circ} 13^{\prime} 15^{\prime \prime}, 1,017 \mathrm{~m}$; 井川, 北緯 $35^{\circ} 12^{\prime} 54^{\prime}$, 東経 $138^{\circ} 14^{\prime} 18^{\prime \prime}, 770 \mathrm{~m}$.

The location and the altitude of each station are: Hakuba, $36^{\circ} 41^{\prime} 42^{\prime \prime} \mathrm{N}, 137^{\circ} 51^{\prime} 54^{\prime \prime} \mathrm{E}, 703 \mathrm{~m}$; Haramura, $35^{\circ} 58^{\prime} 6^{\prime \prime} \mathrm{N}, 138^{\circ} 13^{\prime} 15^{\prime \prime} \mathrm{E}, 1,017 \mathrm{~m}$; Ikawa $35^{\circ} 12^{\prime} 54^{\prime \prime} \mathrm{N}, 138^{\circ} 14^{\prime} 18^{\prime \prime} \mathrm{E}, 770 \mathrm{~m}$.

$(2,899 \mathrm{~m})$, 夏沢峠, 天狗岳 $(2,646 \mathrm{~m})$ を経て麦 草峠に至る南北の主稯線から西側に約 $2.3 \mathrm{~km}$ 隔 てて位置する．編笠山北部の権現岳 $(2,715 \mathrm{~m})$ か ら西に派生する尾根上にある．したがって，西側か らみれば半ば独立峰的な性格を持つ山である. 山体 の北側は八ヶ岳の主稜線から連続する急斜面で，崩 壊地も多い，一方，西および南西側はスムースな平 滑斜面，あるいはやや凸型の斜面が山麓の別荘地帯 （標高 $1,200 \sim 1,300 \mathrm{~m}$ 程度）まで連続する. 本稿 で取り扱うミズナラーチョウセンゴヨウーカラマツ 混交林の分布地付近（標高 $1,850 \sim 2,000 \mathrm{~m}$ ）には 平滑斜面を切り込むようにやや浅い沢（通称カラマ ツ沢，本稿でも今後こう呼ぶ）が南西に流下してい るが (図 1 ), これは山麓の標高 $1,400 \mathrm{~m}$ 付近で消 滅する.

西岳南西斜面一帯は, 更新世中期の西岳溶岩に覆 われる (河内 1977)。これは普通輝石かんらん石玄 武岩からなる（河内 1977）。また，集塊岩，スコリ ア集塊岩, 火山角礫岩が分布し, それらは粒径 1〜 $3 \mathrm{~m}$ の大きな岩塊をなすことが多い。地表面には しばしば岩塊が露出する.土壌は全域が湿性ポドゾ
ルである（国土庁土地局国土調查課 1974）。

\section{2。気候}

ミズナラーチョウセンゴヨウーカラマツ混交林分 布地での気象観測資料はないので, 西岳西麓の原村 （標高 1, $017 \mathrm{~m}$; 北緯 $35^{\circ} 58^{\prime}$ 6”, 東経 $138^{\circ} 13^{\prime} 15^{\prime \prime}$ ) での気温と降水を, 日本海側の白馬（標高 $703 \mathrm{~m}$; 北緯 $36^{\circ} 41^{\prime} 42^{\prime \prime}$, 東経 $\left.137^{\circ} 51^{\prime} 54^{\prime \prime}\right)$ および太平洋 側の井川（標高 $770 \mathrm{~m}$; 北緯 $35^{\circ} 12 ’ 54$ ”, 東経 $138^{\circ} 14^{\prime} 18^{\prime}$ ) のものと比較して, 西岳南西斜面の気 候条件をみてみよう（表 1 ）。白馬および井川を比 較の対象としたのは, アメダス観測地点の中で, 経 度と標高が原村となるべく近いこと，さらに，日本 海および太平洋に距離的により近いこと，を考慮し た結果である. 1979 1990 年の月平均気温の年較 差は白馬 $25.8^{\circ} \mathrm{C}$, 原村 $24.6^{\circ} \mathrm{C}$ 対して, 井川は $20.8^{\circ} \mathrm{C}$ で, 原村は白馬とほぼ同様, 井川と比べると 夏, 冬の気温差がかなり大きい，原村では，夏の最 高気温はほかの 2 地点と大差はないが，冬の最低気 温の低下がより顕著である．年間降水量は白馬 $1,935 \mathrm{~mm}$, 井川 $3,010 \mathrm{~mm}$ に対して, 原村は 
1,317 mm で最も少ない. とくに冬季の降水量が 少ないことが特徵的である. すなわち，日本海側の 白馬は冬季 3 力月（12２ 月）の降水量合計は 403 $\mathrm{mm}$ にのぼるが, 冬季に乾燥する太平洋側の井川 では $295 \mathrm{~mm}$ であり, 原村は $138 \mathrm{~mm}$ で, 井川よ りもさらに少ない.

原村は, 夏冬の気温差が大きく, また, 年間を通 じて降水が少なく, 冬季に低温, 乾燥にさらされる, いわば大陸型の気候条件下にあるといえる. 西岳南 西斜面は原村よりも標高が高いため，冬期の低温は より厳しく, また, 午後に太陽と直面するため, 乾 燥はより著しいであろう。

\section{3. 植生}

西岳では, ミズナラーチョウセンゴョウーカラマ ツ混交林は南西斜面の標高 1,840 2, $010 \mathrm{~m}$ の範囲 に，カラマツ沢で二つの林分に分断されるように分 布する (図 1 参照)，等高線に沿った水平的な分布 距離は二つの林分を合わせて約 $700 \mathrm{~m}$, 垂直的な 分布距離は $300 \mathrm{~m}$ 程度で, それほど広いものでは ない，この一帯は, 本州内陸部に特有な, ブナを欠 くミズナラ優占型落葉広葉樹林の分布上限に当たる (和田 1983). ブナ林はこの付近には分布しない.

この混交林を境に，その上部には亜高山性のシラ ベAbies veitchii Lindl.ーオオシラビソ林および シラベーオオシラビソーダケカンバ Betula ermanii Cham. 混交林が分布する. シラベーオ才 シラビソ林は林冠高 $10 \mathrm{~m}$ あるいはそれ以下で，山 頂付近の西斜面および混交林付近の南西尾根上に主 に分布する. シラベーオオシラビソーダケカンバ混 交林は林冠高 10〜15 m 程度で, シラベーオオシラ ビソ林分布域以外の斜面を広く覆う.

カラマツ沢右岸斜面には, 標高 1,670 1,960 m の範囲にわたってカラマツ天然林が斜面に沿って細 い帯状に分布する. 林冠高は $20 \mathrm{~m}$ 前後に達し, よ く発達した林分である.このカラマツ天然林の最下
部標高 $1,700 \mathrm{~m}$ にヤツガタケトウヒPicea koyamai Shirasawa の小林分が分布する（伊藤 1964; 横内ほか 1966; 杉山・遠山 1987).

ミズナラーチョウセンゴヨウーカラマツ混交林の 下部はカラマツやシラべなどの人工造林地，あるい はミズナラ二次林が分布し, 発達した天然林はみら れない。

\section{III 調 査 方 法}

ミズナラーチョウセンゴヨウーカラマツ混交林の 中に 4 力所の調査区を設けた (図 1 参照)。標高は $1,870 \sim 1,940 \mathrm{~m}$, 斜面方位は南西から南南西, 傾 斜は $15^{\circ}$ 程度で, これらの条件には 4 調査区間で大 きな違いはない（表 2 )。各調査区の面積は 250〜 $460 \mathrm{~m}^{2}$ である.

調查区内に出現する樹高 $2 \mathrm{~m}$ 以上の高木性樹種 (通常樹高 $15 \mathrm{~m}$ 程度以上に達し, 森林の亜高木層, 高木層を構成する樹種) を対象に, 胸高直径 (DBH; 高さ $1.3 \mathrm{~m}$ での幹の直径), 樹高, 垂直樹冠長（樹 木個体全体の中で，実際に葉が茂っている部分，す なわち樹冠の垂直的な長さ), および樹冠投影面上 の長径と短径を測定した、樹冠を楕円形とみなし， 長径と短径から調查樹木個体の樹冠面積を算出した.

\section{IV 結 果}

1. 量的構成と樹種構成

ミズナラーチョウセンゴヨウーカラマツ混交林の 量的構成を表 2 に示す. 各調査区における最大樹高 maximum height は 13 25 m, 最大胸高直径 maximum DBH は 28〜45 cm で, 調査区 $1 \sim 3$ はカラマツ，4 はミズナラのものである，単位面積 あたりの胸高断面積合計 basal area は 32.8〜 42.6 $\mathrm{m}^{2} / \mathrm{ha}$ である. 単位面積あたりの樹冠面積合計 crown area は $0.95 \sim 1.61$ ha/ha である.

樹種構成をみると, ミズナラ, チョウセンゴョウ, カラマツの 3 種で胸高断面積合計の $80 \%$ 程度を占 
め, この 3 種が優占していることがわかる. その他 には, 亜高山帯性樹種 subalpine elements とし てシラベ，ダケカンバ，コメッガ Tsuga diversifolia (Maxim.) Mast., 山地帯性樹種 montane elements としてウラジロモミ Abies homolepis Sieb. et Zucc., シラカンバ Betula platyphylla Sukatchev var. japonica (Miq.) Hara, ウラジ ロノキSorbus japonica (Decne.) Hedl.などが 現れるが，いずれも量的には優占 3 樹種と比べてご く少なく，森林の主要構成樹種ではない，亜高山帯 性樹種と山地帯性樹種の量的割合には著しい違いは なく,この混交林は山地帯最上部, 亜高山帯との境 界付近に分布しているといえる.

優占 3 種について量的構成をより詳しくみると, ミズナラは胸高断面積合計は 32〜 67\% に達し，4 調査区すべてで最も優占する. チョウセンゴヨウも 4 力所すべてに出現し，胸高断面積合計は 6〜19\% にのぼる. カラマツは 4 力所中 3 力所に出現する. 出現する場合は胸高断面積合計は 27 35\% で，ミ ズナラに次いで優占する.

\section{2. 直径分布}

この混交林が一時的なものか, あるいは立地環境 に対応して永続性があるものかを考察するために, 主要 3 種について直径分布を検討した（表 3 )。

胸高断面積合計で最も優占しているミズナラは, 調査区 1 以外の 3 力所では直径 $20 \mathrm{~cm}$ 以下の小径 木の方がそれ以上の大径木よりも本数が多い. 調査 区1でも11 20 cm の小径木は全本数の $24 \%$ ほ ど存在する．全体としては同一林分内で後継樹を確 保しているといえる.

チョウセンゴヨウは, 4 調査区すべてで, 全体の 本数に対して直径 $10 \mathrm{~cm}$ 以下の小径木の本数割合 がきわめて高い，最小でも調査区 1 の $33 \%$ で，他 の 3 調查区はそれ以上である．全体として逆 J 型の 直径分布を示している.この種もミズナラと同様同
表 2 八ヶ岳南部西岳 (標高 $2,398 \mathrm{~m}$ ) 南西斜面に分布 するミズナラーチョウセンゴヨウーカラマツ混交 林 4 調查区での林分の量的構成, および出現樹種 とそれらの胸高断面積割合（\%)

Table 2 Quantitative features, and tree species and their relative abundance (\%) in basal area in the four plots of QuercusPinus-Larix mixed forest on the southwest slope of Mt. Nishi $(2,398 \mathrm{~m}$ in elevation), southern Yatsugatake, central Japan

\begin{tabular}{|c|c|c|c|c|}
\hline Plot & 1 & 2 & 3 & 4 \\
\hline Altitude (m) & 1,920 & 1,940 & 1,910 & 1,870 \\
\hline Aspect & N165W & N150W & N142W & N151W \\
\hline Slope (degrees) & 15 & 15 & 18 & 15 \\
\hline Survey area $\left(\mathrm{m}^{2}\right)$ & 460 & 330 & 250 & 260 \\
\hline Maximum height $(\mathrm{m})$ & 17 & 13 & 25 & 18 \\
\hline Species* & Ll & $\mathrm{Ll}$ & $\mathrm{Ll}$ & $\mathrm{Qm}$ \\
\hline Maximum $\mathrm{DBH}^{* *}(\mathrm{~cm})$ & 45 & 39 & 38 & 28 \\
\hline Species* & $\mathrm{Ll}$ & $\mathrm{Ll}$ & $\mathrm{Ll}$ & $\mathrm{Qm}$ \\
\hline Basal area $\left(m^{2} / h a\right)$ & 37.6 & 42.6 & 32.8 & 39.6 \\
\hline Crown area (ha/ha) & 0.95 & 1.21 & 1.61 & 1.54 \\
\hline
\end{tabular}

Relative abundance in basal area (\%)

Dominant species

$\begin{array}{llllll}\text { Quercus mongolica } & 45 & 32 & 36 & 67\end{array}$

$\begin{array}{lllll}\text { Pinus koraiensis } & 12 & 17 & 6 & 19\end{array}$

$\begin{array}{lllll}\text { Larix leptolepis } & 29 & 27 & 35\end{array}$.

Subalpine elements

$\begin{array}{lllll}\text { Abies veitchii } & 5 & 1 & 9 & 11\end{array}$

$\begin{array}{llllll}\text { Betula ermanii } & 4 & 6 & 1 & 1\end{array}$

Tsuga diversifolia

Montane elements

$\begin{array}{lllll}\text { Abies homolepis } & 1 & \text { - } & 1 & 1\end{array}$

$\begin{array}{llllll}\text { Betula platyphylla } & \text { - } & 10 & 6 & \text { • }\end{array}$

$\begin{array}{lllll}\text { Sorbus japonica } & 3 & 1 & 3 & 1\end{array}$

$\begin{array}{lllll}\text { Prunus incisa } & 1 & 1 & 2 & 1\end{array}$

Pinus densiflora

${ }^{*}$ Ll: Larix leptolepis, Qm: Quercus mongolica, Pk: Pinus koraiensis

**` Diameter at breast height (1. $3 \mathrm{~m}$ in height) 表中のドットは，その種が調査区で不在であることを示す．

The dot in the table means that the species is absent in the plot.

百分率の算出の際に四捨五入したため, 合計は必ずしも $100 \%$ と はならない。

一林分内で後継樹を確保している. 今後, この林分 での優占度は高まるであろう。

カラマツは 3 調査区に出現し, そのすべてで直径 $21 \mathrm{~cm}$ 以上の大径木が分布する. $20 \mathrm{~cm}$ 以下の後 継樹の本数割合をみると, 調查区 1 では $82 \%$ とか 
表 3 八ヶ岳南部西岳（標高 $2,398 \mathrm{~m}$ ) 南西斜面に分布するミズナラーチョ ウセンゴヨウーカラマツ混交林 4 調查区における主要 3 樹種の胸高直 径分布 (本/ha)

Table 3 Diameter at breast height distribution (number/ha) of the three major species in the four plots on the southwest slope of Mt. Nishi (2,398 $\mathrm{m}$ in elevation), southern Yatsugatake, central Japan

\begin{tabular}{lrrrrrrrrrrrrr}
\hline Plot & \multicolumn{1}{c}{$\begin{array}{c}1 \\
\text { Species }^{*}\end{array}$} & $\mathrm{Qm}$ & $\mathrm{Pk}$ & $\mathrm{Ll}$ & $\mathrm{Qm}$ & $\mathrm{Pk}$ & $\mathrm{Ll}$ & $\mathrm{Qm}$ & $\mathrm{Pk}$ & $\mathrm{Ll}$ & $\mathrm{Qm}$ & $\mathrm{Pk}$ & $\mathrm{Ll}$ \\
\hline \multicolumn{1}{l}{ Diameter class $(\mathrm{cm})$} & & & & & & & & & & \\
$0-10$ & 0 & 43 & 195 & 420 & 420 & 0 & 80 & 480 & 80 & 38 & 266 & 0 \\
$11-20$ & 87 & 65 & 0 & 630 & 210 & 0 & 160 & 80 & 0 & 342 & 342 & 0 \\
$21-30$ & 259 & 0 & 0 & 30 & 60 & 60 & 80 & 0 & 80 & 342 & 38 & 0 \\
$31-40$ & 22 & 0 & 0 & 0 & 0 & 90 & 40 & 0 & 80 & 0 & 0 & 0 \\
$41-50$ & 0 & 22 & 43 & 0 & 0 & 0 & 0 & 0 & 0 & 0 & 0 & 0 \\
Total & 368 & 130 & 238 & 1,080 & 693 & 150 & 360 & 560 & 240 & 722 & 646 & 0 \\
\hline
\end{tabular}

*Qm: Quercus mongolica $\quad$ Pk: Pinus koraiensis $\quad$ Ll: Larix leptolepis

なり高いが，2 ではまったく欠け， 3 では $33 \%$ で, 調査区によってばらつきがある，しかし，森林全体 のどこかでは後継樹が生育する可能性があるとみて よい.

\section{$\mathrm{V}$ 考 察}

\section{1. 混交林の発達段階と更新状態}

量的構成からこの混交林の発達段階を明らかにす る. 比較のために, 八ヶ岳南部に分布する, よく発 達した自然林の值をみると, 東斜面の清里高原標高 1,650 m に分布するミズナラ林（川村ほか 1996） では, ミズナラの最大胸高直径 $70 \mathrm{~cm}$ ，最大樹高 $14 \mathrm{~m}$, 胸高断面積 $62.3 \mathrm{~m}^{2} / \mathrm{ha}$ である. また, 西 岳南西斜面カラマツ沢標高 $1,710 \mathrm{~m}$ のカラマツー ヒメマツハダ Picea bicolor (Maxim.) Mayr var. acicularis Shirasawa et Koyama 林（杉山・遠 山 1987) では, カラマツの最大胸高直径 $42 \mathrm{~cm}$, 最大樹高 $28 \mathrm{~m}$, 胸高断面積合計 $64.8 \mathrm{~m}^{2} / \mathrm{ha}$ であ る.これらの値と比べると, 調査地の混交林の值は やや小さい. したがって,この混交林はいまだに十 分には発達しきっていない林分といえる．このこと は，樹冠面積合計が 0.95〜1. 61 ha/ha で，完全に 鬱閉した林分と比べるとまだ小さいことからも裏づ
けられる. たとえば, 上述の清里高原のミズナラ林 では樹冠面積合計は 3.05 ha/ha に達している（川 村ほか 1996)。この例から, $1.6 \mathrm{ha} / \mathrm{ha}$ 程度の值 に達していても, 林冠木間の樹冠の重なりや低木の 存在を考慮すると, いまだ林冠に隙間がわずかに残 っている段階とみてよいであろう. しかし, 胸高断 面積合計は, 最大の調査区 2 では $42.6 \mathrm{~m}^{2} / \mathrm{ha}$ に 達している，佐野（1988）によれば，この値はよく 発達したミズナラ林の標準的な値 $\left(40 \mathrm{~m}^{2} / \mathrm{ha}\right)$ と 等しい. そのため, この混交林はよく発達した森林 にかなり近いものとみなせる.

優占 3 樹種の直径構造からこの混交林の更新状態 を検討する. ミズナラは，小径木の数はあまり多く ないが，4 調査区すべてで胸高直径 $20 \mathrm{~cm}$ 以下の 後継樹を確保している．ミズナラ天然林では，林冠 木に対して後継樹の数が少ないことがむしろ普通で, そうした状況でも，不連続ながら森林は継続的に維 持される (佐野 1988)。チョウセンゴヨウは林内に 後継樹がきわめて多い。この樹種は，マツ属樹木の 中では比較的耐陰性が高いので (Wang 1961; Ageenko 1969), 林冠がある程度疎開して個体に 光が当たるようになれば，林冠木にまで育つ可能性 は高い (Okitsu 1996)。日本列島ではチョウセン 
ゴヨウが同一林分内で順調に更新している例はきわ めて少ない，西岳の混交林がほぼ唯一の例と思われ る.この樹種は今後優占度を増し, いずれはチョウ センゴヨウ優占林へと移り变わって行くであろう. カラマツは大径木が多く, 後継樹の出現は連続的で はない. しかし, 近くのカラマツ沢の天然林から種 子が継続的に供給されていると思われるので, 混交 林内にギャップなどの開放地が生ずればそこで後継 樹が育つ可能性は高い。この樹種もミズナラやチョ ウセンゴヨウと同様にほぼ継続して更新する可能性 が高い.

この混交林は，山火事，あるいは伐採などで広い 面積にわたって開放地が出現し，それをきっかけと してそこへ優占 3 種が順次侵入して, 成立したもの と思われる. そのため, いまだに完全には発達しき っていないのであろう。しかし，優占 3 樹種はそれ ぞれほぼ順調に更新している。このことは, 西岳南 西斜面の環境はそれら 3 樹種の分布に適しているこ とを示している. 仮にこの 3 種が, 開放地ができた ためにそこに偶然侵入し, 環境自体は必ずしも適し てはいないものの，たまたま現在まで生き延びてい るとすれば，これらの更新は必ずしも順調ではない であろう。したがって, この混交林は, 成立そのも のは開放地が出現したことによるとはいえ, 気候条 件をはじめとする西岳南西斜面の現在の環境に対応 した，永続性のある存在といえる．将来は，チョウ センゴヨウが量的に増加して最優占樹種となり, そ こにミズナラが混生し, カラマツが単木的に点在す る林分へ移り変わって, それが継続してゆくであろ う.

この混交林が永続性のある存在であることを裏づ けるために, 西岳南西斜面でのチョウセンゴヨウや ミズナラの分布を文献などから確認してみる. 林 (1952) の記載によれば, 西岳南西斜面では標高 1,800 2, $300 \mathrm{~m}$ の範囲でチョウセンゴヨウの分布 量が比較的多い（林の記載で稍多, 多).また, 杉
山・遠山（1987）によれば，カラマツ沢に分布する ヤツガタケトウヒ林やカラマツーヒメマツハダ林で は, チョウセンゴヨウやミズナラが, 個体数はそれ ほど多くないものの, 後継樹を確保している. 筆者 の観察でも, この混交林の周囲のミズナラ二次林内 にはチョウセンゴヨウの後継樹が頻繁にみられた。 こうしたことは, この混交林が, 西岳南西斜面の現 在の環境に対応した永続性のある存在であることを 裏づけている.

\section{2. 地理的分布}

この混交林の地理的分布を検討する. 樹種構成の 特徵はミズナラ, チョウセンゴヨウ, カラマツが共 優占することである. チョウセンゴョウの量的割合 が比較的高いことは日本列島においては比較的珍し い（林 1951，1952; 沖津・百原 1997)。このことか ら，この混交林と類似する林分は，日本列島内では かなり少ないことが予想される. そこで，この混交 林と類似した林分が日本列島のほかの地域に存在す るか否かを知るために，日本植生誌（宮脇 1982， 1985，1986，1987）を検討した。これは日本列島の 植生について出現植物の種類組成を中心にきわめて 詳細に記述したものである. 群落単位ごとに出現植 物の種類組成が一つひとつの調査区ごとに記され， 群落組成表として示されている. 仮にこの混交林と 類似した森林が日本列島のいずれかに存在するなら ば，日本植生誌に集録されている可能性がきわめて 高い. チョウセンゴヨウの分布範囲を覆うように, 四国・中部・関東・東北の各地方における群落組成 表を検討した。 しかし，この混交林之類似する組成 を持つ林分は記録されていなかった。 したがって, 西岳のミズナラーチョウセンゴョウーカラマツ混交 林は，日本列島ではほかに例が知られていない特異 的な森林といえよう。西岳は，日本列島の中ではき わめて珍しい分布地と考えられる。

一方, 朝鮮半島北部, 中国東北地方からロシア沿 
海州にかけての，汎針広混交林帯が分布する地域 (Tatewaki 1958) では, この混交林之類似の森林 が分布する (図 1 参照)。その地域では，垂直分布 の下方から上方に向かって, 主要な森林タイプとし て，モンゴリナラを主体とする落葉広葉樹林，チョ ウセンゴヨウー落葉広葉樹混交林, カラマツ類 Larix gmelinii (Rupr.) Rupr. を含むエゾマツ Picea jezoensis (Sieb. et Zucc.) Carr.ートウシ ラベ Abies nephrolepis (Trautv.) Maxim. 林 が順に現れる (沖津 1993). モンゴリナラとチョウ センゴヨウとが共優占して森林を形成することは少 ないが，それでも，モンゴリナラを主体とする落葉 広葉樹林とチョウセンゴヨウ一落葉広葉樹混交林と の境界付近では，この両種が混生する森林が現れる。 その場合, チョウセンゴヨウが優占し, モンゴリナ ラが混生する, チョウセンゴョウーモンゴリナラ混 交林となる例が多い，そうした森林は中国黒竜江省 (並川・王 1996), 沿海州南部 (石川 1996), シホ テーアリニ山脈北部アニュイ川流域（沖津 1997） などから報告されている，それらの量的構成をみる と, 黒竜江省のものでは最大樹高 $24 \mathrm{~m}$, 胸高断面 積合計 $53.8 \mathrm{~m}^{2} / \mathrm{ha}$ (並川・王 1996), 沿海州南部 では最大樹高 $25 \mathrm{~m}$, 胸高断面積合計 $640 \mathrm{~m}^{2} / \mathrm{ha}$ （石川 1996）といった值が報告されている．これら の値は西岳の混交林のものと比べて大きく, 大陸域 の混交林はより発達していることがわかる，また， チョウセンゴヨウとカラマツ類とが混生する林分も アニュイ川流域では広い範囲でみられる（沖津 1997). 西岳の混交林が, 標高的には山地帯最上部 に位置し，覀高山帯針葉樹林との境界付近に分布す ること, 将来はチョウセンゴョウーミズナラ混交林 へと移行する可能性が高いことを考慮すると, この 混交林は大陸域でのチョウセンゴョウーモンゴリナ ラ混交林ときわめて類似性が高いといえる.

以上のことから, この混交林は, 日本列島内部に 分布するものの, 実際には北東アジア大陸部の森林
ときわめて類似性が高く, 日本列島では独自の存在 であると結論できる. 北東アジア大陸部のチョウセ ンゴヨウーモンゴリナラ混交林が西岳に隔離分布し ているとみなしてよいであろう.

そうした類似性を西岳の気候条件から検討してみ よう. 先に記したように, 西岳南西斜面は, 中部日 本の中では気温の年較差が大きく, 年間を通じて降 水が少ない乾燥気候下にある. とりわけ冬期の寒冷, 乾燥が著しい. 西岳南西斜面では, 午後に太陽と直 面するため，乾燥はより著しくなる，岩礫が分布す ることも乾燥環境を増幅するであろう。岩礫地では 水が岩礫の隙間から流下しやすいばかりでなく, 土

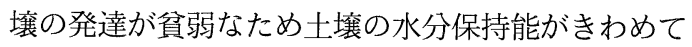
低いためである. 大陸部でのチョウセンゴョウ一落 葉広葉樹混交林分布域の気候条件を検討するために, 混交林分布域南部に位置する中国吉林省撫松（長白 山の北西約 $100 \mathrm{~km}$, 北緯 $42^{\circ} 40^{\prime}$, 東経 $127^{\circ} 10^{\prime}$ ) での観測資料 (王 1987) をみと, 年平均気温 $4.3^{\circ} \mathrm{C}$, 最暖月（7月）の平均気温 $21.9^{\circ} \mathrm{C}$, 最寒月（1月） の平均気温 $-16.5^{\circ} \mathrm{C}$, 年平均降水量 $763 \mathrm{~mm}$, そ のうち冬期の 3 力月（12２月）の降水量合計は $27.1 \mathrm{~mm}$ である. 大陸部でのチョウセンゴョウー 落葉広葉樹混交林の分布範囲は西岳よりもかなり北 に, しかも, 内陸域に位置するために (図 1 参照), 撫松は原村と比べて年平均気温が低く, 気温の年較 差が $38.4^{\circ} \mathrm{C}$ に達し，降水は少なく，とくに冬期の 乾燥は激しい，それでも，原村の気候条件は，日本 海側の白馬, 太平洋側の井川と比べると，撫松のも のにより近い. したがって, 日本列島内でチョウセ ンゴヨウーモンゴリナラ混交林の気候的分布適地を 求めるならば，西岳南西斜面は最も適した地域とい えよう。

西岳を含む中部日本内陸域には，日本海側や太平 洋側の地域では普通にみられるブナ林は分布せず, それに代わって，北東アジア大陸部に分布するモン ゴリナラ（ミズナラ）優占型落葉広葉樹林が分布す 
る（和田 1983）。ブナ林は冬期の乾燥に弱いことが 知られている（島野 1998）。そのため，こうしたブ ナ林の欠如は, 西岳南西斜面が大陸的な気候条件下 に近いことを示唆している.

3. ミズナラーチョウセンゴヨウーカラマツ混交 林の植生変遷史上の意義

以上のように，西岳のミズナラーチョウセンゴョ ウ一カラマツ混交林は, 必ずしも完全に発達しきっ たものではないが, 構造, 更新の面から, 北東アジ ア大陸部に分布するチョウセンゴヨウーモンゴリナ ラ混交林と類似していることが明らかとなった。し かし，こうしたタイプの林分は日本列島では現在西 岳の狭い範囲に限定分布していると考えられる。こ の点を手がかりとして, この混交林の持つ植生変遷 史上の意義を考察する.

最終水期には, より寒冷, 乾燥な大陸的な気候が 中部日本では卓越していたことが地形学や古植物学 の面から明らかにされている（亀井ほか 1981; 辻 1983，1987; Ono 1984). 日本列島でもチョウセン ゴョウは本州の広範囲に分布し（辻 1983），さまざ まな樹種と混生していた。西南日本から中部日本 の沿岸域では, 河川下流の平野部でハンノキ属 Alnus, ハシバミ属Corylus, カエデ属 Acer, サ クラ属Prunus, ブナ属Fagus などの落葉広葉樹 と混生していた（たとえば, 南木・松葉 1985; 辻 ほか 1985). 一方, 中部日本の内陸域や東北日本で はモミ属Abies, ツガ属 Tsuga, トウヒ属Picea などの針葉樹と混生していた（たとえば，Sohma 1959; 吉田ほか 1981). したがって, 最終氷期には 本州中部にチョウセンゴヨウーミズナラ混交林が存 在していた可能性は高い。

ところが, 後氷期になって, 日本列島はより温暖, 湿潤な気候条件に変化した，それと呼応して，最終 水期に, 寒冷, 乾燥気候条件下で中部日本に広がっ ていたチョウセンゴョウーミズナラ混交林は，その
後の温暖, 湿潤化に伴い, 寒冷, 乾燥の卓越する大 陸的な気候条件を追う形で, 西岳南西斜面へ逃げ込 み, 残存したと考えられる。

この混交林の残存過程をより具体的に考察する. 後水期の気候の湿潤, 温暖化に伴い, 中部日本では, 落葉広葉樹林が現在の分布上限である標高 $1,850 \mathrm{~m}$ 程度（和田 1983）まで分布を拡大した。西岳にお いても, 落葉広葉樹林が斜面上部に向かって優勢に 分布拡大する中で, チョウセンゴョウーモンゴリナ ラ混交林は, 落葉広葉樹林上限と亜高山性のシラベ 一オオシラビソ林やシラベーオオシラビソーダケカ ンバ混交林分布下限（図 1 参照）の境界域の狭い地 域, 標高 $1,900 \mathrm{~m}$ 前後に追い込まれる形となった. そこは冬期に乾燥し, 低温で, 気温の年較差が比較 的大きい，大陸的な気候条件であったので，この混 交林は分布可能であった．後氷期を通じて，チョウ センゴヨウーモンゴリナラ混交林は南西斜面標高 $1,900 \mathrm{~m}$ 付近で細々と森林を維持してきたのであ ろう。近年になって人為の影響が著しくなり，伐採 や人工造林が進み，山火事が起こる之，西岳南西斜 面の森林は二次林や人工造林地が主体となって行く. しかし，伐採や山火事による開放地の出現は，それ まで残存していたチョウセンゴヨウの更新には好適 に作用した．さらに，本来の二次林要素であるミズ ナラ（和田 1983）も, 開放地の出現は更新にとっ てむしろ好都合である. そのため, 後水期を通じて 細々と森林を維持してきたこの混交林にとって, 伐 採や山火事による開放地の出現は森林の維持に対す る阻害要因にはなり得なかったであろう.

現在西岳に分布するミズナラーチョウセンゴョウ 一カラマツ混交林は，それ自体は伐採や山火事跡地 に成立したものではあろうが，最終水期に大陸的な 気候条件のもとで成立していたチョウセンゴヨウー ミズナラ混交林の種類組成や更新特性を継承してい るものと考えられる. したがって，この混交林を， 伐採, 山火事跡地に偶然に成立し, 今後は衰退して 
ゆく，一時的な存在ととらえることは適切ではない． この混交林は最終水期からの遺存植生に類する性格 を有しているとみてよいであろう. 実際, 西岳周辺 には，最終水期時には分布を拡大していたトウヒ属 バラモミ節樹木 Picea sect. Picea Farjon（辻ほ か 1984; 辻 1987) のヤツガタケトウヒが点在し, 同様に分布を拡大していたカラマツも分布量が多い （舘脇ほか 1965）。

この混交林の以上のような分布変遷を支持する傍 証として, 満鮮要素の分布がある. 堀田 (1974) は, 日本列島において中国東北部から朝鮮半島と共通し た分布をする植物（満鮮要素）11 種（ザリコミ Ribes Maximowiczianum Komarov，ザイフリ ボク Amelanchier asiatica (Sieb. et Zucc.) Endlicher，コゴメウッギ Stephanandra incisa (Thunb.) Zabel など）の分布を明らかにしてい る.こうした満鮮要素は西岳を含む中部日本内陸域 で最も多く分布し，そこでは 10 種以上を数える. そこを中心に，日本列島を西，あるいは北に向かう につれて, 満鮮要素の分布数は減少する.これらの 植物は, 日本列島が現在よりさらに乾燥, 寒冷な時 期に分布を拡大し，最終水期に分布型を完成したと 考えられているものが多い（堀田 1974）。後水期の 温暖, 湿潤化に伴い, 満鮮要素は, 現在最も大陸的 な中部日本の内陸部に閉じこめられた格好となって いる。

これまでの考察をまとめると, 西岳西南斜面は, 最終水期のチョウセンゴヨウ一落葉広葉樹混交林の レフュジーア（待避場所）として機能している可能 性が指摘できる. 西南向き斜面という地形条件, 気 候条件, さらに, 土壌の乾燥条件をもたらす存在と しての岩塊の分布などからみて，ここは，最終水期 のチョウセンゴヨウー落葉広葉樹混交林のレフュジ 一アとなり得る有力な場所の一つであろう.

現地調查に際しては野手啓行君（千葉大学大学院自然
科学研究科）に手伝っていただいた，記して感謝する. 本研究には平成 $10,11,12$ 年度文部省科学研究費補助金 （基盤研究 C (2), 代表者沖津 進, 課題番号 10680097) を使用した。

（投稿 1999 年 1 月 30 日）

(受理 1999 年 5 月 8 日)

\section{文 献}

石川幸男 1996。 ロシア共和国沿海州南部の森林における 主要樹種の分布と生長. 専修大学北海道短期大学紀要 29: 15-73.

伊藤浩司 1964. 日本森林植生雑記 (1), 北海道大学農学 部邦文紀要 5: 59-76, 2 Plates.

沖津 進 1993。シホテ・アリ二山脈に分布するチョウセ ンゴヨウー落葉広葉樹混交林からみた北海道の針広混交 林の成立と位置づけ：地理学評論 66: 555-573.

沖津 進 1997. シホテーアリ二山脈北部アニュイ川流域 の森林植生. 植生学会誌 14: 129-139.

沖津 進・百原 新 1997。 日本列島におけるチョウセン ゴヨウ (Pinus koraiensis Sieb. et Zucc.) の分布. 千葉大学園芸学部学術報告 51: 137-145.

梶 幹男 1982. 亜高山性針葉樹の生態地理学的研究. 才 オシラビソの分布パターンと温暖気候の影響. 東京大学 農学部演習林報告 72: 31-120.

亀井節夫・ウルム氷期以降の生物地理総研グループ 1981. 最終水期における日本列島の動・植物相. 第四紀研究 20: 191-205.

河内晋平 1977。『八ヶ岳地域の地質』地域地質研究報告 ( 5 万分の 1 図幅), 地質調查所.

川村美岐・遠山三樹夫・星 直斗・山本詠子 1996。清里 高原におけるミズナラ林について. 横浜国立大学教育学 部野外教育実習施設研究報告 14: 1-20.

国土庁土地局国土調查課監修 1974。 『土地分類図（長野 県)』財団法人日本地図センター.

佐野淳之 1988。群落構造の解析による天然性ミズナラ林 の更新様式に関する研究. 北海道大学農学部演習林研究 報告 45: 221-266.

島野光司 1998. 何が太平洋が太平洋型ブナ林の更新を妨 げるのか? 植物地理・分類研究 46: 1-21.

杉田久志 1990 . 後水期のオオシラビソ林の発達史一一分 布特性にもとづいて，植生史研究 6: 31-37.

杉山克之・遠山三樹夫 1987。西岳のヤツガタケトウヒと ヒメマツハダの群落について. 横浜国立大学教育学部野 外教育実習施設研究報告 5: 1-8.

舘脇 操・伊藤浩司・遠山三樹夫 1965 . カラマツ林の群 落学的研究. 北海道大学農学部演習林研究報告 $24: 1$ 176, 14 Plates. 
辻 誠一郎 1983. 後期更新世の自然環境一とくに立川 期を中心として. 季刊考古学 4: 17-20.

辻 誠一郎 1987. 最終氷期以後の植生史と変化様式一 将来予測に向けて. 日本第四紀学会編『百年, 千年, 万 年後の日本の自然と人類. 第四紀研究に基づく将来予 测』157-183. 古今書院.

辻 誠一郎・南木睦彦・鈴木三男 1984. 栃木県南部, 二 宮町における立川期の植物遺体群集. 第四紀研究 23: 21-29.

辻 誠一郎・吉川昌伸・吉川純子・能城修一 1985. 前橋 台地における更新世末期から完新世初期の植物化石群と 植生. 第四紀研究 23: 263-269.

並川寛司・王 風春 1996. 中国黒竜江省, 寧安県, 小北 湖林場のチョウセンゴヨウ一落葉広葉樹混交林の構造.

森林立地 38: 35-42.

林 弥栄 1951. 日本産重要樹種の天然分布一一針葉樹第

1 報. 林業試験場研究報告 48: 1-240.

林 弥栄 1952. 日本産重要樹種の天然分布一一針葉樹第

2 報. 林業試験場研究報告 55: 1-251.

堀田 満 1974. 『植物の進化生物学 III. 植物の分布と分 化』三省堂.

南木睦彦・松葉千年 1985 .三重県多度町から産出した約 18,000 年前の大型植物遺体群集. 第四紀研究 24: 5155.

宮脇 昭編 1982.『日本植生誌 3 四国』至文堂.

宮脇 昭編 1985. 『日本植生誌 6 中部』至文堂.

宮脇 昭編 1986. 『日本植生誌 7 関東』至文堂.

宮脇 昭編 1987. 『日本植生誌 8 東北』至文堂.

百原 新 - 水野清秀 - 沖津 進 1997. 近畿地方南部, 菖 蒲谷層上部層の前期更新世末寒冷期の大型植物化石群. 植生史研究 5: 29-37.

守田益宗 1984. 東北地方における亜高山帯の植生史につ いて—I 吾妻山. 日本生態学会誌 34: 347-356.

守田益宗 1985. 東北地方における亜高山帯の植生史につ いて一一II 八幡平. 日本生態学会誌 35: 411-420.

守田益宗 1987. 東北地方における亜高山帯の植生史につ いて一一III 八甲田山. 日本生態学会誌 37: 107-117. 守田益宗・相沢俊二 1986. 東北地方北部の亜高山帯の植 生史に関する花粉分析的研究. 東北地理 38: 24-31.

安田喜憲・三好教夫編 1998, 『図説日本列島植生史』朝倉 書店.

横内 斎・横内文人・飯沼冬彦 1966. ヤツガタケトウヒ の研究. 長野林友 1966: 2-31.

吉田 義 - 伊藤七郎 - 白瀬美智男 - 堀内俊秀 - 真鍋健一 鈴木敬治 - 竹内貞子 - 野中俊夫 - 榆井良正 - 榆井典子 1981. 阿武隈山地中央部における第四系と植物化石群 一一最終水期における東北日本南部の植生変遷の一例. 第四紀研究 20: 143-163.
和田 清 1983. 本州中央部の内陸地域における夏緑広葉 樹林の植物社会学的研究 (II). 信州大学教育学部紀要 48: 221-254.

王 季平編 1987. 『長白山志』長春 : 吉林文史出版社.

Агеенко, А. С. [Ageenko, А. S.] (Редак.) 1969. Леса Далынего Востока. Москва: Издательстово Лесная Промышленносты.

Critchfield, W. B. and Little, E. L. Jr. 1966. Geographic distribution of the pines of the World. Washington: USDA, Forest Service, Misc. Publ.

Лавренко, Е. М. и Сочава, В. Б. [Lavrenko, Е. М. and Sochava, V. B.] 1954. Геоботаническая Карта СССР. Маситаб 1 : 4,000,000. Ботанический Институт им. В. Л. Комарова. Ленинград: Академия Наук Союза CCCP.

Hou, H.-Y. 1983. Vegetation of China with reference to its geographical distribution. Annals of the Missouri Botanical Garden 70: 509-548.

Okitsu, S. 1996. Growth characteristics and regeneration manner of the Korean pine (Pinus koraiensis Sieb. et Zucc.) on Mt. Changbai, northeastern China. Natural Environmental Science Research 9: 9-14.

Ono, Y. 1984. Last Glacial paleoclimate reconstructed from glacial and periglacial landoforms in Japan. Geographical Review of Japan 57B: 87-100.

Sohma, K. 1959. On woody remains from a Pleistocene peaty lignite at Otani, Aomori Prefecture. Ecological Review 15: 67-70.

Sugita, H. 1992. Ecological geography of the range of the Abies mariesii forest in northeast Honshu, Japan, with special reference to the physiographic conditions. Ecological Research 7: 119-132.

Tatewaki, M. 1958. Forest ecology of the islands of the north Pacific ocean. Journal of the Faculty of Agriculture, Hokkaido University 50: 371-486, 30 Plates.

Wang, C.-W. 1961. The forest of China. Cambridge: Harverd University.

Yamanaka, M., Saito, K. and Ishizuka, K. 1973. Historical and ecological studies of Abies mariesii on Mt. Gassan, the Dewa mountains, northeast Japan. Japanese Journal of Ecology 23: 171-185.

Yim, Y.-J. 1977. Distribution of forest vegetation and climate in the Korean Peninsula: IV. Zonal distribution of forest vegetation in relation to thermal climate. Japanese Journal of Ecology 27: 269278 . 


\title{
Stand Structure of the Quercus mongolica-Pinus koraiensis-Larix leptolepis Mixed Forest on the Southwest Slope of Mt. Nishi, Central Japan, and the Significance of the Mixed Forest in Vegetation History since the Last Glacial Period
}

\author{
Susumu OKITSU (Faculty of Horticulture, Chiba University)
}

A mixed forest dominated by Quercus mongolica, Pinus koraiensis, and Larix leptolepis occurs on the southwest slope of Mt. Nishi (2,398 m in elevation), southern Yatsugatake mountains, central Japan, covering the altitudinal range from 1,840 to $2,010 \mathrm{~m}$. This paper introduces the quantitative features of the mixed forest and the size structure of the three dominant species, and discusses the significance of the mixed forest in the vegetation history since the Last Glacial period in Japan.

Quercus mongolica dominates the mixed forest followed by Larix leptolepis in the total basal area. Pinus koraiensis occurs constantly although in smaller numbers than those of the preceding two species. The mixed forest still remains in the stage of the secondary forest, after a mountain fire or clear cutting. However, the relatively higher total basal area of the mixed forest (ca. $42 \mathrm{~m}^{2} / \mathrm{ha}$ ) indicates that this forest is approaching the mature stage. All of the three dominant species maintain their successional individuals within the forest, of which Pinus koraiensis is the most abundant. The mixed forest is self-maintaining, adjusting to the cold and dry, continental climatic conditions of the southwest slope of Mt. Nishi. In the future, it is assumed that the mixed forest will change its quantitative composition with the greater prevalence of Pinus koraiensis followed by Quercus mongolica.

The co-occurrence of Quercus mongolica and Pinus koraiensis within the same forest is unique in Japan. In the continental part of northeastern Asia, however, a similar forest appears in the transitional area from a Quercus mongolica-dominated forest to a Pinus koraiensis-deciduous broad leaved mixed forest. The mixed forest of Mt. Nishi is regarded as a disjunction from the forest of the continent.

Paleobotanical and geomorphological evidence indicates that the cold and dry continental climate during the Last Glacial period produced the Pinus koraiensis-Quercus mongolica mixed forest in central Japan. The postglacial warming and moistening may have forced the mixed forest to the southwest slope of Mt. Nishi as a refuge. The present mixed forest of Mt. Nishi is considered to be a descendant of the Last Glacial forest, a relict from the Last Glacial period.

Key words: continental climate, refuge, Pinus koraiensis, Last Glacial period, vegetation history 